\title{
Tourism activities and companies in a sustainable adventure tourism destination: the Azores
}

\section{Atividades e empresas de animação turística num destino sustentável de turismo de aventura: os Açores}

\author{
João Ponte \\ Fundo de Maneio, Ponta Delgada, Portugal, jcrispim@fundodemaneio.com
}

\section{Gualter Couto}

School of Business and Economics and CEEApIA, Universidade dos Açores, Ponta Delgada, Portugal, gualter.mm.couto@uac.pt

Pedro Pimentel

School of Business and Economics and CEEApIA, Universidade dos Açores, Ponta Delgada, Portugal, pedro.ms.pimentel@uac.pt

\section{André Oliveira}

Fundo de Maneio, Ponta Delgada, Portugal, aoliveira@fundodemaneio.com

\begin{abstract}
The Azores is one of the most sustainable nature-based island destinations in the world. Local tourism activities companies are vital to tourists' adventure experiences. These businesses' portfolios were analysed using various editions of the official Tourism Activities Guide. The analysis focused on companies' products, types of activities, geographical coverage and brands. The generalised profile generated indicates that these firms each operate on only one island, have a small portfolio and are prone to specialise in sea or land activities. Snorkelling and motor boat rides are the most common sea activities, while nature hikes and walks, van tours and cultural tours are the most widely offered land activities. Explicit or indirect references to the Azores and adventure often appear in companies' brands, which is in line with international trends in adventure tourism. However, company profiles are changing due to the impacts of a new air transport model.
\end{abstract}

Keywords: Tourism activities, tourism companies, adventure tourism, sustainable tourism, Azores.

\section{Introduction}

Smith (1994) states that tourism products are, fundamentally, experiences and, without a clear statement of the nature of the tourism product (in the most general sense) and how it is produced, creative and successful product development is hindered. In a more focused analysis, Buckley (2006) underlines the lack of research on the structure of adventure tourism products and associated business aspects. In emerging adventure destinations, these issues may have significant economic and environmental impacts both in the short and long run.

The Azores is a Portuguese autonomous region composed of nine islands located in the middle of the Atlantic Ocean, almost midway between Europe and the United States of America. The archipelago is strategically positioned as a sustainable nature-based destination. It has been increasingly identified with adventure tourism by international references like Bloomberg, Departures, BBC, Forbes, GeekyExplorer, and Lonely Planet, among many others. Vieira et al. (2014) notice that each of the nine islands has its own identity. All islands share an extraordinary natural legacy but also have their

\section{Resumo}

Os Açores são um dos destinos insulares de natureza mais sustentáveis do mundo. As empresas de animação turística locais são vitais para experiências de aventura. Utilizando várias edições do Guia de Atividades de Animação Turística, analisaram-se os seus portfolios. A análise foca-se nos produtos e tipos de atividades oferecidas pelas empresas, na cobertura geográfica, e nas marcas. O perfil geral indica que operam em apenas uma ilha, dispõem de pequenos portfolios, e são propensas à especialização em atividades terrestres ou marítimas. "Snorkelling" e "passeios de barco a motor" são as atividades marítimas mais comuns, enquanto "passeios na natureza", "passeios de carrinha", e "tours culturais" são as atividades terrestres mais disseminadas. Referências explícitas ou indiretas aos Açores ou aventura surgem frequentemente nas marcas, em linha com as tendências internacionais no turismo de aventura. Porém, o perfil das empresas está a alterar-se devido ao impacto causado pelo novo modelo de transporte aéreo.

Palavras-chave: Animação turística, atividades turísticas, turismo de aventura, turismo sustentável, Açores.

unique landscape, traditions, cuisine, and architecture, which generate a vast touristic potential. Silva and Almeida (2013) also observe that every island has the potential and strengths to develop active, nature, adventure, and sports tourism. These incredible natural resources and cultural identity provide the basis for unforgettable adventure tourism experiences in the region. Moreover, the partial liberalisation of air transport in the Azores, which occurred in March 2015 and induced the start of low-cost airlines operations, has been increasing the number of tourists (especially first-time tourists) and favouring a significant change in the local market (Couto, Pimentel \& Ponte, 2017). The local economy is changing, and increasing investment is being directed to tourism activities, ranging from accommodation to entertainment. Nonetheless, the Azores archipelago has natural constraints that demand constant attention. The heterogeneous territory's fragmentation resulted in nine very different islands regarding area and natural resources, with significant land dispersion (some islands are very distant from the centre of the archipelago, while others are very close to each other). For this reason, five islands - Santa Maria, Graciosa, São Jorge, Flores, and Corvo - have been identified 
as the "Cohesion Islands" (being the smallest islands or the ones with more significant challenges to their development) and benefit from positive discrimination in the regional economic policies. The remaining four islands - São Miguel, Terceira, Pico, and Faial - are the most developed, although substantial differences exist.

Tourism is perceived as a sector of high strategic importance for the Azores, which can contribute in a decisive way to the development and growth of the region (Vieira et al., 2014). Nature and adventure tourism are frontline products of this paradigm. Nevertheless, a lack of supply and players in these market segments have been recently identified, even though nature-based tourism products stand out as the ones with the highest potential (Couto et al., 2017). As a consequence of the new tourism sector dynamics, more and more tourism activities companies and businesses are being created, diversifying the supply of tourist experiences, especially activities connected to nature and adventure.

There are numerous businesses in the adventure tourism sector (Tshipala, Coetzee, \& Potieter, 2014), but little attention has been devoted to the structure of individual adventure tourism products (Buckley, 2006; Cole, 2016) or the companies that offer these services. Arnegger, Woltering and Job (2010) refer that the massive growth of tourism since the 1950 s benefited from and, to a great extent, was driven by the application of the Fordist modes of production and consumption to tourism through the offer of highly standardised, inflexible package tours to a large number of customers. Moreover, while Steynberg and Grundling (2005) legitimately question whether adventure tourism fits the "alternative tourism" umbrella, various authors suggest that adventure and nature tourism are often placed in that category (Arnegger et al., 2010; Silva \& Almeida, 2013; Tshipala et al., 2014). According to Arnegger et al. (2010), alternative and nature-based tourism assume a post-Fordist paradigm, which can justify the little attention given to their product structuring, through the angles that Smith (1994) and Buckley (2006) uphold.

It seems, thus, essential to developing research efforts focused on nature and adventure tourism activities, their product structuring, and the companies and professionals that operate in these market niches. In that regard, Buckley (2006) suggests that economic statistics, which aim to identify how many businesses offer what products, where, and at what price, represent a research priority. The goal of this paper is to provide insights into these open issues in the Azores context, an adventure tourism destination with increasing market awareness and attractiveness and still in an early stage of its life cycle.

\section{Literature review}

Arnegger et al. (2010) suggest that tourism segmentation is particularly tricky since tourism's system is very complex, with a hybrid of multi-type tourists and multi-layered production structures. The authors recognise that the consumers of nature-based tourism are a rather heterogeneous group, although more highly educated and more critical than Fordist mass tourists. They base their analysis on Goodwin (1996), who states that this tourism category comprehends all forms of tourism - mass tourism, adventure tourism, low-impact tourism, and ecotourism - that use natural resources in wild or undeveloped form. It is clear that, beyond more complex segmentation issues, adventure tourism is intrinsically associated with nature.

\subsection{Adventure tourism: activities and product structure}

Adventure tourism is one of the fastest growing markets in the tourism sector, but it is also one of the least understood forms of tourism, and it has received relatively little research attention (Buckley, 2006; Steynberg \& Grundling, 2005; Tshipala et al., 2014). Nonetheless, due to the increasing importance of its demand and consumer profile, its potential to contribute to sustainable development and attract people and investment to rural areas, and its ability to explore remote regions with insufficient infrastructures, adventure tourism has been the target of increasing awareness. However, there is no consensual definition of adventure tourism yet, although the definition provided by the Adventure Travel Trade Association (ATTA) has been adopted by the World Tourism Organization (UNWTO): a trip that includes at least two of the following three elements: physical activity, natural environment, and cultural immersion (UNWTO, 2014; pp 10). Buckley $(2006 ; 2007)$ states that adventure tourism broadly means guided commercial tours where the principal attraction is an outdoor activity, which relies on features of the natural terrain and requires specialised sporting or similar equipment. Adventure tourism is also generally exciting for the tour clients. However, several variables contribute to the complete description of this market segment, and not all of them are universally unquestioned.

A number of activities characterize adventure tourism, including climbing, caving, abseiling, sea kayaking, whitewater kayaking, rafting, diving, snorkelling, skiing, snowboarding, surfing, sail boarding, sailing, ballooning, skydiving, parapenting, horse riding, mountain biking, snowmobiling, off-road driving, river expeditions, and wildlife watching (Buckley, 2007). ATTA's list is also very diversified and slightly more generic, and cultural immersion has a relevant role in its definition, as evidenced in the Global Report on Adventure Tourism (UNWTO, 2014).

The valorisation of active and sports tourism, especially in nature, has contributed to the global expansion of the tourism activities sector (Silva \& Almeida, 2013). In this regard, it is critical to recall that the services provided by the tourism industry must be refined by consumers to adequately customise the final output, personal experiences (Smith, 
1994). Buckley (2007) suggests that the dynamics of the industry, the behaviour of the people involved, their destinations and impacts are all intimately linked with the structure of the tourism products offered to retail consumers. Furthermore, in the specific adventure tourism market, different types of adventure activities and consumers coexist, and unique definitions do not exist. ATTA's guidelines classify adventure tourism in two categories, hard adventure and soft adventure, although adventure is a very subjective experience and directly related to the individual perception (e.g., what is risky for someone may not be for another) (UNWTO, 2014).

Adventure activities are somewhat diversified. The majority of such activities are distinguishable by commercial as well as operational criteria and have a recognisable commercial signature measured by the duration and price per person per day (Buckley, 2007). Cole (2016) suggests the presence of a distinct commercial signature for guided, destination-based mountain bike tours by cost, riding style, tour duration, fitness and skill requirements, and departure dates. The level of commercialisation of a given activity also appears to influence the profile of its participants (Giddy, 2017), and different variables have a direct impact on adventure product structuring and attractiveness, including skill requirements, group size, client-to-guide ratio, access and remoteness, duration, equipment, and accommodation. All these aspects are interrelated and affect the price per person per day (Buckley, 2007).

Interestingly, Giddy (2017) suggests that commercial adventure tourism participants seek new types of experiences rather than building on past experiences and potentially developing specific skills. Besides, Buckley (2007) shows that the main bulk of the adventure market consists of highvolume, low difficulty products for unskilled clients. To complement, UNWTO (2014) states that adventure travellers rank areas of natural beauty as the most important factor in choosing their most recent destination, followed by the available activities and climate.

\subsection{Adventure Tourism and Sustainability}

Steynberg and Grundling (2005) address the sustainability of tourism and claim that the impact of adventure tourism is tied to the volume of activities in a given destination. At the same time, Tshipala et al. (2014) state that concerns have been raised about the impact that adventure tourism could have on the environment and the surrounding communities. A direct connection exists between nature and adventure tourism since this type of activities takes place in areas that are not adapted to mass tourism because of their remoteness and unique natural or cultural heritage (Steynberg \& Grundling, 2005). Therefore, promoting their sustainability and the due preservation of the local, often fragile, resources is essential. Research on these topics is of the utmost importance, as protected area management bodies, institutions related to environmental preservation and conservation, and nature- based tourism management organizations need data and tools to address the changing characteristics and consumption behaviour of tourists that visit those fragile environments (Arnegger et al., 2010; Giddy, 2017).

Steynberg and Grundling (2005) also suggest that adventure tourism's economic development should include the following dimensions, beyond the appropriate changes in the structure of the economic activity and the improvements in the distribution of income and wealth:

- the balance between investment in adventure tourism infrastructure and adventure tourism consumption (activities and events);

- the equilibrium between the adventure tourism offerings and the costs associated with such an offer;

- the continuous improvements (productivity) in the methods employed to foresee the needs of the adventure tourist.

Sustainability issues in tourism have been historically hard to overcome because different interpretations exist for their core definition. Tshipala et al. (2014) notice that some groups view sustainable tourism as a means for protecting the natural and cultural environment for the future generations, while others see it as a means for ensuring an ongoing flow of tourists both in the short and long term. McMinn (1997) offers some insight to this debate by suggesting that the challenge of sustainable tourism is that, as a goal, it sounds both right and viable, but as an objective, it may not be so easily achieved. Kozak (1999) claims that the future competitiveness of destinations will be based on the extent to which they are concerned with their sustainability. Tshipala et al. (2014) also conclude that stakeholders see sustainable indicators as necessary for the development of sustainable tourism industry, contributing towards the development of sustainable adventure destinations and the reduction of negative impacts on the environment.

Steynberg and Grundling (2005) remind that, by acting as a vehicle for economic interaction between developed and developing regions, adventure tourism transfers the concerns of sustainable development to some of the world's most remote places. Furthermore, Silva and Almeida (2013) state that, predominantly, natural peripheral regions with a strong cultural identity are the ones that should "invest" in a sustainable tourism model supported by niche tourism - like adventure tourism - trying to diversify the supply for different small scale and low impact market segments. As such, since adventure tourism has been identified as both an economic and social development growth driver, it should also be environmentally sustainable. In particular, the actions of adventure tourists should not compromise the ability of future generations to sustain their livelihood (Steynberg \& Grundling, 2005). 


\subsection{The case of the Azores}

Baldacchino (2006) argues that cold water island destinations have a much more limited touristic potential compared to warm water islands, especially because atmospheric and sea conditions are frequently unfavourable. Due to reduced touristic demand and high seasonality, the development opportunity of the tourism sector in those territories is limited to niche tourism, generally linked to local culture and history and nature and adventure tourism, based on environmental observation and nature sports. The Azores fits somewhere in between cold and warm waters islands. The climate is mild, with high levels of humidity and regular rain, although the rainy periods are generally short. The main characteristics of this destination are the peace and quietness, an unspoiled nature, various outdoor activities (ranging from extreme sports to golf), and heartfelt hospitality (Vieira et al., 2014).

According to Silva and Almeida (2013), the tourism activity in the Azores is related to natural beauty and the possibility to have peaceful, active, and exotic holidays. This region stands out as an excellent destination for active nature, wellness, and adventure tourism. Natural elements play a critical role in the competitiveness of the Azorean tourism. Santos, Couto, Pimentel and Vieira (2012) reveal that landscape, weather/climate, hospitality, cleanness, and safety were the most appreciated indicators of quality indicated by tourists in the Azores. Vieira et al. (2014) demonstrate that higher levels of satisfaction with the climate, security, nature and landscape, environmental quality, and quality/price of local hotels contribute the overall satisfaction with the Azores as a tourist destination. Couto et al. (2017) underline that the Azores has exceptional natural conditions, with diversified resources, which allow the lure of different markets.

Silva and Almeida (2013) argue that regions such as the Azores have great potential for the development of nature and adventure tourism products, but, due to their early stage of development as a destination and limitations in the carrying capacity, it is necessary to guarantee a sustainable tourism development model, focused on the endogenous resources to achieve the diversification of tourism products, to satisfy visitors expectations, and, assure the minimization of the impact of tourism activities. In line with Butler's (1980) and Buhalis' (2000) approach to the destination life cycle, a careful destination planning and tourism development management seems of critical relevance to avoid some of the impacts associated to maturity and saturation stages, like polluted environment and landscapes, decay of heritage, water pollution, erosion, and congestion and traffic.

Sustainability in the Azores is taken very seriously by local authorities and is considered a critical factor for the region's tourism sector. In 2007, National Geographic Traveler elected the Azores as the Second-Best Islands for Sustainable Tourism, with relevant appraisals to the natural environment and cultural diversity. However, it was also pinpointed that inappropriate development was beginning to appear. Silva and Almeida (2013) note that individuals and companies that offer canyoning activities in the Azores are aware that the environment is an indispensable asset for the quality of their product and, therefore, actively contribute to its conservation. However, with the recent tourism outburst, several problems related to hiking trails maintenance and traffic congestion have emerged in some popular local attractions, such as Lagoa do Fogo, Caldeira Velha or Sete Cidades. Whale watching, one of the most emblematic tourism activities in the Azores, has also suffered significant setbacks. In 2009, oversight efforts on whale watching activities were reinforced due to some in compliance with local regulations, a problem that Scarpaci, Dayanthi and Corkeron (2003) had already detected in Port Philip Bay (Australia). In 2010, the Regional Government established additional restrictions on the whale watching activities and limited access to licenses as a result of increasing pressure on the whales, dolphins, and their calves. In this regard, Buckley (2007) notices that wildlife watching tours (the ones that are marked as adventure tourism) are expensive because most of them involve small groups and highly skilled guides or trackers viewing large and potentially dangerous animals in relatively remote areas, with specialised transport and upmarket accommodation. Thus, it is on the destinations' and local practitioners' best interest to comply with regulations to protect the wildlife, which directly contributes to a destination's attractiveness and businesses profitability.

Nature and adventure tourism allow the reinforcement of the image or the Azores as a destination, not only through nature tourism, ecotourism, and contemplation but also through action. In the Azores, it is not just possible to see, but also do and feel unforgettable emotions (Silva \& Almeida, 2013). Increasing promotional efforts has been carried on to nourish this market positioning, with many local natural resources and iconic destinations becoming central assets of relevant outdoor competitions and adventure events, including the Azores Mountain Bike Marathon, the Azores Airlines Pro (Surf), the Azores Airlines Rallye, the Azores Trail Run, the Ecologic Trail Run, the Azores World Formula Windsurfing Championship, the Azores Airlines Big-Game Fishing, the Red Bull Cliff Diving, the Epic Trail Run Azores, the Azores Challenge Trail, the AZAB - The Azores and Back (Yacht Race), the VISSLA ISA World Junior Championship (Surf), the Rubis Gas Hot Air Balloon Festival of Ribeira Grande, the Billabong Azores Island Pro (Surf), and the BirdRace Açores (Birdwatching), among others.

The potential of this region as a tourist destination is somehow hindered by the limitations imposed by its climate, which can be overcome through the quality of the offer, an essential factor in the region's distinction (Santos et al., 2012). Silva and Almeida (2013) go even further stating that the Azores should diversify and qualify the tourism supply through more differentiated activities and services. This is one of the major challenges for local tourism activities companies and tourism entrepreneurs. Despite a recent positive evolution, the supply 
of tourism services is still often unstructured and supported by individual and isolated initiatives, without a common strategic course (Couto et al., 2017), with an adverse impact on the destination's development and qualification.

In a research conducted by Couto et al. (2017) concerning the strategic planning process for tourism development in Ribeira Grande (one of the biggest municipalities of the Azores), tourists explicitly indicated that adventure packs and more walking/hiking trails would be on their wish list for future visits. Moreover, Ayala's (1996) research results revealed that environmental quality is a decisive factor in the destination choice for one out of every two German tourists, and this is, at present, the biggest foreign market for the Azores tourism. Notwithstanding these positive indications, tourism product structuring and business development in the Azores are closely linked to the quality of the products and services, as emerging markets are becoming increasingly competitive (Santos et al., 2012).

\section{Method}

This research is exclusively based on secondary data. Multiple sources of information were consulted, but the Tourism Activities Guide developed by Turismo dos Açores - Convention and Visitors Bureau (ATA) (a not-for-profit private association who has the mission to promote the Azores in strategic source markets) was the essential source of information for this study as it incorporates a comprehensive listing of tourism activities companies in the Azores. This is in line with Buckley (2007), who suggests resources like tour operator marketing materials as possible sources of information to analyse adventure product structuring. In this study, we tried to validate the following assumptions: 1) the Azores is (or can be considered) an adventure tourism destination; and 2) the Azores is a sustainable tourism destination.

The ATA kindly provided access to all Tourism Activities Guide publications, allowing the analysis of different years and the possibility to compare the tourism activities companies profile before and after the new air transport model, introduced in 2015. Nevertheless, the timeframe is somewhat limited, as the data used in this study only covered four editions: $2013 / 2014$, 2014/2015, 2015/2016, and 2017/2018 (there was no $2016 / 2017$ edition). The editions before $2013 / 2014$ - namely, 2011/2012 and 2012/2013 - only had data regarding seven of the nine islands of the Azores, and one of the two omitted islands was São Miguel, the biggest, most populated, and the one with more tourism activity and tourism companies. The ATA's technical staff were also very helpful in explaining the procedures to produce this guide, allowing a more comprehensive understanding of its scope.

The Tourism Activities Guide listed various activities organised in different categories. For each of the nine islands of the archipelago, an indication of the tourism companies that provided access to each of the mentioned activities was presented. This essential information allowed the construction of quantitative data outputs, which underlined the general profile of the tourism activities companies as well as the specific activities carried on in each island. Each edition of the guide did not include all the tourism activities companies in the Azores, but only those that sent the information required by the ATA. Nevertheless, the guides report a very substantial portion of the local players and provide a reliable perspective on the overall company profiles. The ATA collects these data on an annual basis, through direct contact with each company, which is usually established on the last trimester of the year (for instance, for the 2014/2015 issue, companies' information was requested in the last trimester of 2014). Since there was no 2016/2017 edition, the information for the 2017/2018 issue was collected in December 2016 and published in October 2017. Therefore, the available information represents a continuum, which starts in 2013 and finishes in 2016, although it is identified by the $2013 / 2014,2014 / 2015,2015 / 2016$, and 2017/2018 editions.

To confirm that the Azores is an adventure tourism destination, the activities listed in the Tourism Activities Guide were compared with the list of adventure tourism activities presented by the ATTA (UNWTO, 2014). This procedure was aimed at understanding whether a relevant portion of the local supply could be considered adventure tourism, thus positioning the Azores as an adventure tourist destination on the market. Whenever a direct correspondence between Azorean tourism activities and the ATTA's listing could not be found, the core concept of the activity was compared with Buckley's (2007) definition and product listing. This comparison was also established with the ATTA's definition of adventure tourism to check whether the analysed activity had a least two of the three elements indicated by the ATTA: physical activity, natural environment, and cultural immersion.

It should also be mentioned that the list of activities reported in the guide presented slight differences from year to year due to the ATA's data analysis decisions. For that reason, some information was lost and limited the assessment of some of the activities and, to some extent, the general conclusion. To guarantee coherence in the analysis, the activities that had consistent information but suddenly disappeared from the guide were still considered in the analysis as indicators of the diversity of the supply of tourism activities in the Azores. This situation happened with the following activities:

Diving courses: all editions of the guide had information about this activity except for the $2017 / 2018$ edition. Diving courses were not included in the survey that the ATA sent to tourism companies. In support of this decision, it can be argued that this is a product related to training and not to tourism and the revenues that companies obtain from this product are mostly derived from locals and not tourists.

Bird watching (sea): all editions had information about this activity except for the $2017 / 2018$ edition. In support of this decision, it can be argued that this is not a specific product per 
se, but an element that is often incorporated in other activities, like whale watching, since the biologists that operate on the boats generally offer information about other wildlife beyond whales and dolphins.

Jet sky: the 2013/2014 and 2014/2015 editions reported information on this activity, which was, instead, not mentioned in the following editions, 2015/2016 and 2017/2018. The company that offered jet sky discontinued this activity although it maintained other tourism offers.

Hot air balloon tours: all editions had information about this activity except for the $2017 / 2018$ edition. The only company on the list that offered this activity did not answer the ATA's survey for that year.

Paragliding and paratrike: this activity only appeared on the last edition of the guide (2017/2018). This is, in fact, a new product, offered by a recently created company, still under licensing.

On a final assessment, companies' naming/branding was also addressed to understand how they presented themselves. This was done at two levels: 1) every company name in each edition was analyzed to identify how many companies had explicit references to the Azores (the criterion was the word "Azores" or "Açores" or derivatives, like "azor," "açor," "azorica," etc.) or indirect references, like the name of an island, place, or town; 2) companies' names were assessed to understand whether they had explicit references to adventure tourism (the criterion was the word "adventure" or derivates like "adventour") or indirect references like "extreme," "fun," "sport," "outdoor" or even adventure activities references (like "diving").

Concerning the assumption that the Azores is a sustainable tourism destination, an analysis of the tourism intensity and tourism density in the region was conducted and, then, complemented with a brief review of the sustainability of the tourism activities. Tourism density was calculated as the relation between the number of tourists and the area of the local territories measured in square kilometres. Tourism intensity was assessed according to the European Commission methodology, stated in the reference document "Environment and Tourism in the Context of Sustainable Development, DGXIEC" (1993). The same methodology is also used by the National Statistical Institute of Portugal (INE), and reads as follows:

$$
T I=\frac{N}{P}
$$

where:

- Tl: tourism intensity;

- N: nights spent at tourist accommodation establishments (thousands);

- P: total permanent resident population of the area (hundreds).

- Sustainable Tourism: $\mathrm{TI}<1,1$;

- Low Sustainability Tourism: $1,1 \leq \mathrm{TI} \leq 1,5$;

- Unsustainable Tourism: $\mathrm{TI}>1,5$.

Statistical information (namely, the number of guests in accommodation establishments), nights spent at tourist accommodation establishments, local residents, and island area were obtained from the official data of the Azores Statistical Office (SREA) online database. It is important to highlight the absence of actual records regarding the real number of tourists that travel to the Azores. Therefore, a proxy was used in the analysis, considering that the number of tourists is equal to the number of guests in tourist accommodation establishments.

\section{Results}

The official statistical records show that the tourism activity in the Azores is increasing. The number of tourists (measured by the number of guests in accommodation establishments) is rising, and all nine islands have had positive evolutions, although significant differences exist. The nine islands have very different dimensions and natural constraints, which impose limits on their carrying capacity. The tourism intensity calculations show that, in the analysed periods, this indicator is always inferior to 1,1 in the Azores, although it differs across islands (see Table 1). Tourism intensity has been steadily increasing in the last two years of the analysis, which coincide with the deployment of the new air transport model.

Table 1 - Tourism density and tourism intensity by island

\begin{tabular}{|c|c|c|c|c|c|c|c|c|c|}
\hline Period & $\begin{array}{c}\text { Santa } \\
\text { Maria }\end{array}$ & $\begin{array}{c}\text { São } \\
\text { Miguel }\end{array}$ & Terceira & Graciosa & $\begin{array}{c}\text { São } \\
\text { Jorge }\end{array}$ & Pico & Faial \\
\hline Tourism Density & & & & & & \\
\hline
\end{tabular}

Source: Own elaboration. 
Concerning the sustainability awards, the Azores have been mentioned and rewarded in several sustainability and sustainable tourism initiatives. All these awards were identified through the ATA's website (www.visitazores.com), but only the ones that have a clear and objective methodology were selected to compose the list reported in Table 2.

Table 2 - Azores sustainability and sustainable tourism awards

\begin{tabular}{|c|c|c|c|}
\hline Award & Organisation & Comments & Year \\
\hline $\begin{array}{l}\text { Top } 10 \text { Most Sustainable World } \\
\text { Destinations }\end{array}$ & Green Destinations & $\begin{array}{l}\text { First place in "Best of the Atlantic" } \\
\text { category }\end{array}$ & 2018 \\
\hline $\begin{array}{l}\text { Top } 100 \text { Most Sustainable World } \\
\text { Destinations }\end{array}$ & Green Destinations & 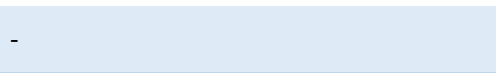 & 2017 \\
\hline QualityCoast Platinum Award & $\begin{array}{l}\text { QualityCoast - Coastal and Marine } \\
\text { Union of the European Union }\end{array}$ & $\begin{array}{l}\text { On par with two other Dutch destinations } \\
\text { - Goedereede and Westvoorne }\end{array}$ & 2017 \\
\hline $\begin{array}{l}\text { Top } 100 \text { Most Sustainable World } \\
\text { Destinations }\end{array}$ & Green Destinations & - & 2016 \\
\hline $\begin{array}{l}\text { Top } 100 \text { Most Sustainable World } \\
\text { Destinations }\end{array}$ & Green Destinations & First place, with 8.9 points out of 10 & 2014 \\
\hline QualityCoast Platinum Award & $\begin{array}{l}\text { QualityCoast - Coastal and Marine } \\
\text { Union of the European Union }\end{array}$ & $\begin{array}{l}\text { First and, at the time, the only destination } \\
\text { with this award }\end{array}$ & $\begin{array}{l}2014- \\
2016\end{array}$ \\
\hline QualityCoast Gold Award & $\begin{array}{l}\text { QualityCoast - Coastal and Marine } \\
\text { Union of the European Union }\end{array}$ & Best Quality Coast Destination in Europe & 2013 \\
\hline Best of the Best - Nature Award & European Commission & $\begin{array}{l}\text { Granted to Project "Life Priolo," which } \\
\text { was developed between } 2003 \text { and } 2008 \text {, } \\
\text { aimed at the protection and restoring of } \\
\text { the risk vegetation of the laurel forest of } \\
\text { the Azores }\end{array}$ & 2010 \\
\hline $\begin{array}{l}\text { Second Best Islands in the World } \\
\text { for Sustainable Tourism }\end{array}$ & National Geographic Traveler & 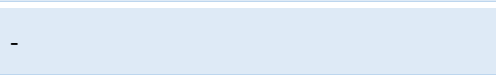 & 2010 \\
\hline Biosphere Reserves & UNESCO & $\begin{array}{l}\text { Island of Flores } \\
\text { Island of Graciosa } \\
\text { Island of Corvo }\end{array}$ & $\begin{array}{l}2007 \\
2007 \\
2009\end{array}$ \\
\hline Natura Network 2000 & European Commission & $\begin{array}{l}23 \text { Special Preservation Areas } \\
15 \text { Special Protection Areas } \\
2 \text { Important Locations of the Community }\end{array}$ & 1989 \\
\hline UNESCO World Heritage & UNESCO & $\begin{array}{l}\text { Landscape of Pico Island Vineyard Culture } \\
\text { Historical Centre of Angra do Heroísmo }\end{array}$ & $\begin{array}{l}1983 \\
2004\end{array}$ \\
\hline
\end{tabular}

Source: Own elaboration.

Table 3 details the results of the identification of adventure tourism activities in the Azores. A very objective and nonflexible approach was favoured, which may not identify some activities as of adventure essence, although they may have, in fact, important adventure elements. The Tourism Activities Guide organises the activities into three main categories - sea activities, land activities, and air activities - and, in some years, also shows which companies offer their services in packs. As the information for packs is not available for the last year of the considered timeframe, the analysis only focusses on the three main categories mentioned above, although brief and occasional considerations are introduced for data concerning packs. In total, 31 of the 37 activities listed on the Tourism Activities Guide can be easily matched with the activities listed in the ATTA's adventure tourism table.

\section{Table 3 - Matching tourism activities in the Azores with ATTA's adventure tourism table}

\begin{tabular}{|c|c|c|c|}
\hline & $\begin{array}{l}\text { Adventure } \\
\text { Tourism }\end{array}$ & Matching with ATTA's Adventure Tourism Table & Type \\
\hline \multicolumn{4}{|l|}{ Sea Activities } \\
\hline $\begin{array}{l}\text { - Whale and Dolphin } \\
\text { Watching }\end{array}$ & $\mathrm{x}$ & $\begin{array}{l}\text { Not listed in ATTA's table, but involves physical activity and natural environment. } \\
\text { Considered to be similar to Birdwatching and can also be integrated into "Wildlife } \\
\text { watching" in Buckley's (2007) list. }\end{array}$ & Soft \\
\hline $\begin{array}{l}\text { - Swimming with } \\
\text { Dolphins }\end{array}$ & $\mathrm{x}$ & $\begin{array}{l}\text { Not listed in ATTA's table, but involves physical activity and natural environment. } \\
\text { Considered to be similar to Snorkeling and can also be integrated into "Wildlife } \\
\text { watching" in Buckley's (2007) list. }\end{array}$ & Other \\
\hline - Diving Trips & $\mathrm{x}$ & Scuba Diving & Soft \\
\hline - Diving Courses & $x$ & Scuba Diving & Soft \\
\hline - Initiation to Diving & $x$ & Scuba Diving & Soft \\
\hline - Diving with Sharks & $\mathrm{x}$ & Scuba Diving & Soft \\
\hline - Snorkelling & $x$ & Snorkelling & Soft \\
\hline
\end{tabular}




\begin{tabular}{|c|c|}
\hline & $\begin{array}{l}\text { Adventure } \\
\text { Tourism }\end{array}$ \\
\hline - Motor Boat Rides & $x$ \\
\hline - Inter-Island Trips & $x$ \\
\hline - Recreational Fishing & $x$ \\
\hline $\begin{array}{l}\text { Spearfishing/Underwate } \\
\text { r fishing }\end{array}$ & $x$ \\
\hline - Sailing & $x$ \\
\hline - Canoeing & $x$ \\
\hline - Bird Watching (sea) & $x$ \\
\hline $\begin{array}{l}\text { - Surfing and } \\
\text { Bodyboarding }\end{array}$ & $x$ \\
\hline - Jet Sky & $x$ \\
\hline - Beach Activities & $x$ \\
\hline - Stand Up Paddle & $x$ \\
\hline \multicolumn{2}{|l|}{ Land Activities } \\
\hline $\begin{array}{l}\text { - Nature Hikes and } \\
\text { Walks }\end{array}$ & $x$ \\
\hline - Cultural Tours & $x$ \\
\hline - Climb to Pico Mountain & $x$ \\
\hline - Bird Watching & $x$ \\
\hline - 4x4 (Jeep) Tours & $x$ \\
\hline \multicolumn{2}{|l|}{ - Van Tours } \\
\hline - Bike Tours & $x$ \\
\hline \multicolumn{2}{|l|}{$\begin{array}{l}\text { - Other Motor Vehicles } \\
\text { (ex. Tuk Tuk) }\end{array}$} \\
\hline - Activities with Horses & $x$ \\
\hline - Geotourism and Caving & $x$ \\
\hline \multicolumn{2}{|l|}{ - Golfing } \\
\hline \multicolumn{2}{|l|}{ - Rustic Golf } \\
\hline - Climbing and Abseiling & $x$ \\
\hline $\begin{array}{l}\text { - Canyoning and } \\
\text { Cascading }\end{array}$ & $x$ \\
\hline - Coasteering & $x$ \\
\hline - Paintball & \\
\hline - Health and Wellness & \\
\hline \multicolumn{2}{|l|}{ Air Activities } \\
\hline - Hot Air Balloon Tours & $x$ \\
\hline $\begin{array}{l}\text { - Paragliding and } \\
\text { paratrike }\end{array}$ & $x$ \\
\hline
\end{tabular}

\section{Matching with ATTA's Adventure Tourism Table}

Not listed in ATTA's table, but involves cultural immersion and natural environment. Considered to be similar to Cruise.

Not listed in ATTA's table, but involves cultural immersion and natural environment. Considered to be similar to Cruise.

Fishing/Fly-fishing

Not listed in ATTA's table, but involves physical activity and natural environment. Considered to be similar to Fishing/Fly-fishing, Snorkeling and Hunting.

Sailing

Canoeing

Birdwatching

Surfing

Not listed in ATTA's table, but involves physical activity and natural environment. Has some resemblances to snowmobiling (which is in Buckley's (2007), list), although it is done in the sea.

Not listed in ATTA's table, but involves physical activity and natural environment.

Not listed in ATTA's table, but involves physical activity and natural environment. Considered to be similar to Surfing.

Hiking / Walking tours

Cultural activities / Getting to know the locals / Visiting historical sites

Climbing (mountain) / Hiking

Birdwatching

Not listed in ATTA's table. Considered to be similar to off-road driving in Buckley's (2007) list.

Not listed in ATTA's table, but involves physical activity and natural environment. It is also mentioned in Buckley's (2007) list.

Was not considered as adventure tourism, although it may have some elements of it because the core experience of this activity is mainly related to tuk-tuk rides in urban/rural areas.

Not listed in ATTA's table, but mentioned in Buckley's (2007) list.

Caving / Environmentally sustainable activities $-$

\section{Climbing (mountain/rock/ice)}

Not listed in ATTA's table, but involves physical activity and natural environment. Considered to be similar to Climbing.

Not listed in ATTA's table, but involves physical activity and natural environment. Considered to be similar to Climbing.

Soft

Soft

Soft

Soft

Soft

Other

Other

Soft

Soft

Other

Hard/

Soft

Soft

Othe -

Not listed in ATTA's table, but mentioned in Buckley's (2007) list.

Other Not listed in ATTA's table, but considered to be similar to Skydiving and Parapenting which are mentioned in Buckley's (2007) list.

Source: Own elaboration.
Specifically concerning tourism activities and companies, the number of companies that answered the ATA's survey has rapidly increased since 2013 and more than doubled in four years. Only 67 companies were listed in the 2013/2014 edition and became 149 in the 2017/2018 edition. In relative terms, the "Cohesion Islands" - Santa Maria, Graciosa, São Jorge, Flores, and Corvo - experienced the fastest growth. Santa Maria, in particular, shows an incredible performance, increasing $1.150 \%$ from 2013/2014 to 2017/2018. Nevertheless, São Miguel maintained and even reinforces its leading position, concentrating $52,3 \%$ of the companies listed in the guide (Graph 1). Only Graciosa, Faial, Flores, and Corvo had slight economic decrease over the years, as shown in the 2015/2016 edition (compared to the previous edition). 
Graph 1 - Number of tourism activities companies in the Tourism Activities Guide, by island

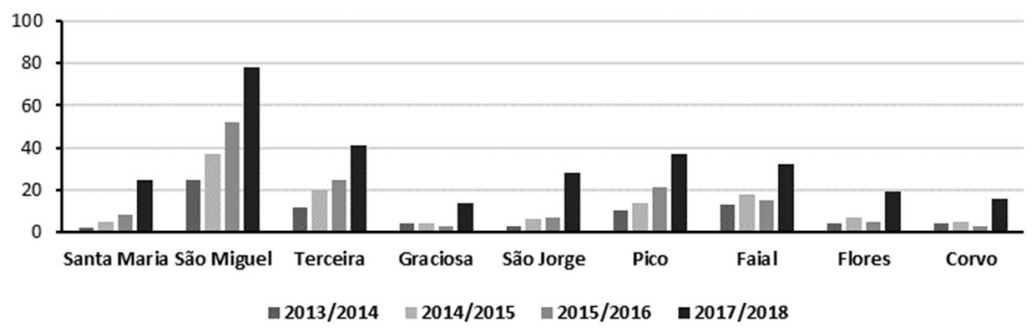

Source: Own elaboration.

The number of companies listed in the guide forms a representative sample of the overall market, as shown by the INE's official statistics for 2013, 2014, and 2015 (see Table 4). The data consider the following official Portuguese Classification of Economic Activities: 93293 - Organization of activities of tourism animation, and 93294 - Other entertainment and recreational activities. Nevertheless, some caution is needed when comparing the official statistics with the guide's lists because some of the companies listed on the guide may have a different Classification of Economic Activity for their primary activity (which is the one that counts for official statistics). This classification issue imposes some limitations on the analysis. However, it is easy to recognise that the sample provided by the guide in each year is representative.

Table 4 - Number of companies officially registered in the Azores whose main Classification of Economic Activity falls under tourism activities

\begin{tabular}{|l|c|c|c|}
\hline & $\mathbf{2 0 1 3}$ & $\mathbf{2 0 1 4}$ & $\mathbf{2 0 1 5}$ \\
\hline Tourism activities organization & 52 & 55 & 75 \\
\hline Other entertainment and recreational activities & 46 & 42 & 48 \\
\hline Total & $\mathbf{9 8}$ & $\mathbf{9 7}$ & $\mathbf{1 2 3}$ \\
\hline
\end{tabular}

Source: Own elaboration.

The vast majority of the companies tends to operate in only one island. This proportion increased until 2015/2016, but the results from 2017/2018 show a much more diversified approach to geographic coverage, with an increasing number of companies operating in all nine islands (see Graph 2).

Graph 2 - Number of islands where companies operate

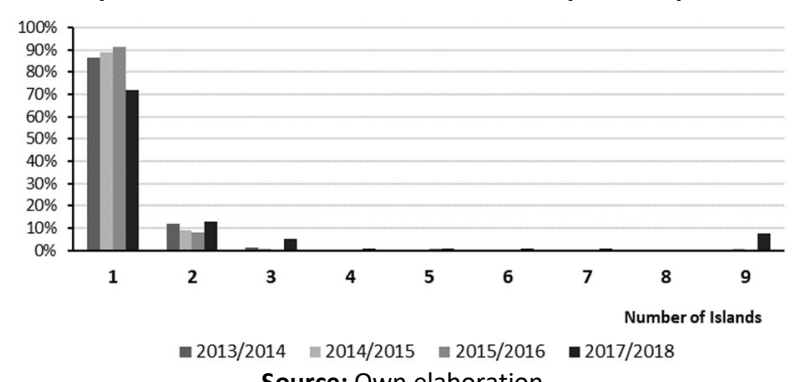

Source: Own elaboration.

Tourism activities companies in the Azores have a small portfolio of services, on average. Traditionally, around one in four companies only offered one activity, although the average was around four activities per company. The most recent data show that companies began offering an increasing number of services and activities (see Graph 3).

\section{Graph 3 - Number of activities in tourism activities companies' portfolios}

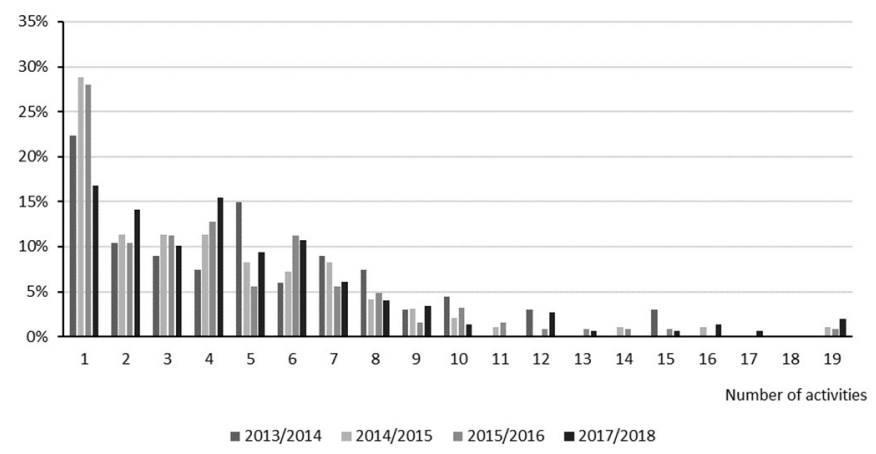

Source: Own elaboration. 
Sea and land activities are the most popular among the companies' portfolios. Air activities are almost non-existent. The first two analysed editions (2013/2014 and 2014/2015) of the Tourism Activities Guide show that sea activities were offered by even more companies than land activities, but the last two editions (2015/2016 and 2017/2018) indicate the opposite trend. In this regard, it is important to recall that the new air transport model was introduced in the Azores in 2015. Some specific sea activities have lost relative importance during the analysis' timeframe: for instance, in 2013/2014 "whale watching" was present in $22,4 \%$ of the portfolios and in $2015 / 2016$ was only present in $10,7 \%$ of the companies' offers.

It is also relevant to notice that many companies only offer a specific category of activities, and this kind of specialisation was more prominent in companies that provide sea activities but has been recently adopted by companies that offer land activities (Table 5). In 2013/2014, 53,3\% of the firms that proposed sea activities were only dedicated to this kind of activity; on the other hand, $41,5 \%$ of the companies that developed land activities were exclusively devoted to this category. The $2017 / 2018$ edition's data show that $53,7 \%$ of the firms offering sea activities were exclusively dedicated to this category, while $68,7 \%$ of the companies providing land activities were only targeting this segment.
Table 5 - Number of companies by category of tourism activity

\begin{tabular}{|r|l|c|c|}
\hline Period & Activity Category & Total & \% of Total \\
\hline \multirow{2}{*}{$2013 / 2014$} & Sea & 45 & $\mathbf{6 7 , 2 \%}$ \\
\cline { 2 - 4 } & Land & 41 & $\mathbf{6 1 , 2 \%}$ \\
\cline { 2 - 4 } & Air & $\mathbf{1}$ & $\mathbf{1 , 5 \%}$ \\
\hline \multirow{2}{*}{$2014 / 2015$} & Sea & $\mathbf{6 2}$ & $\mathbf{6 3 , 9 \%}$ \\
\cline { 2 - 4 } & Land & $\mathbf{5 2}$ & $\mathbf{5 3 , 6 \%}$ \\
\hline \multirow{2}{*}{$2015 / 2016$} & Air & $\mathbf{7 2}$ & $\mathbf{1 , 0 \%}$ \\
\hline \multirow{2}{*}{$2017 / 2018$} & Sea & $\mathbf{7 7}$ & $\mathbf{6 1 , 6 \%}$ \\
\hline & Land & $\mathbf{1}$ & $\mathbf{0 , 8} \%$ \\
\hline & Air & $\mathbf{8 0}$ & $\mathbf{5 3 , 7} \%$ \\
\hline & Sea & $\mathbf{9 9}$ & $\mathbf{6 6 , 4 \%}$ \\
\hline & Land & $\mathbf{1}$ & $\mathbf{0 , 7} \%$ \\
\hline & Air & \\
\hline
\end{tabular}

The 2017/2018 data also show that "snorkeling" (31,5\%), "motorboat rides" (30,2\%), "inter-island trips" (18,8\%), "recreational fishing" $(17,4 \%)$, "canoeing" $(16,1 \%)$ and "diving" $(15,4 \%)$ were the most common sea activities in the companies' portfolios. Nevertheless, all of them, except "snorkelling," have lost relative importance since 2013/2014. Taking into account land activities in 2017/2018, "nature hikes and walks" (47,7\%), "van tours" (40,9\%), "cultural tours" (36,2\%), "4x4 (jeep) tours" $(26,8 \%)$, "bike tours" $(21,5 \%)$ and "birdwatching" $(18,1 \%)$ were the most widespread activities in the supply (see Graph 4).

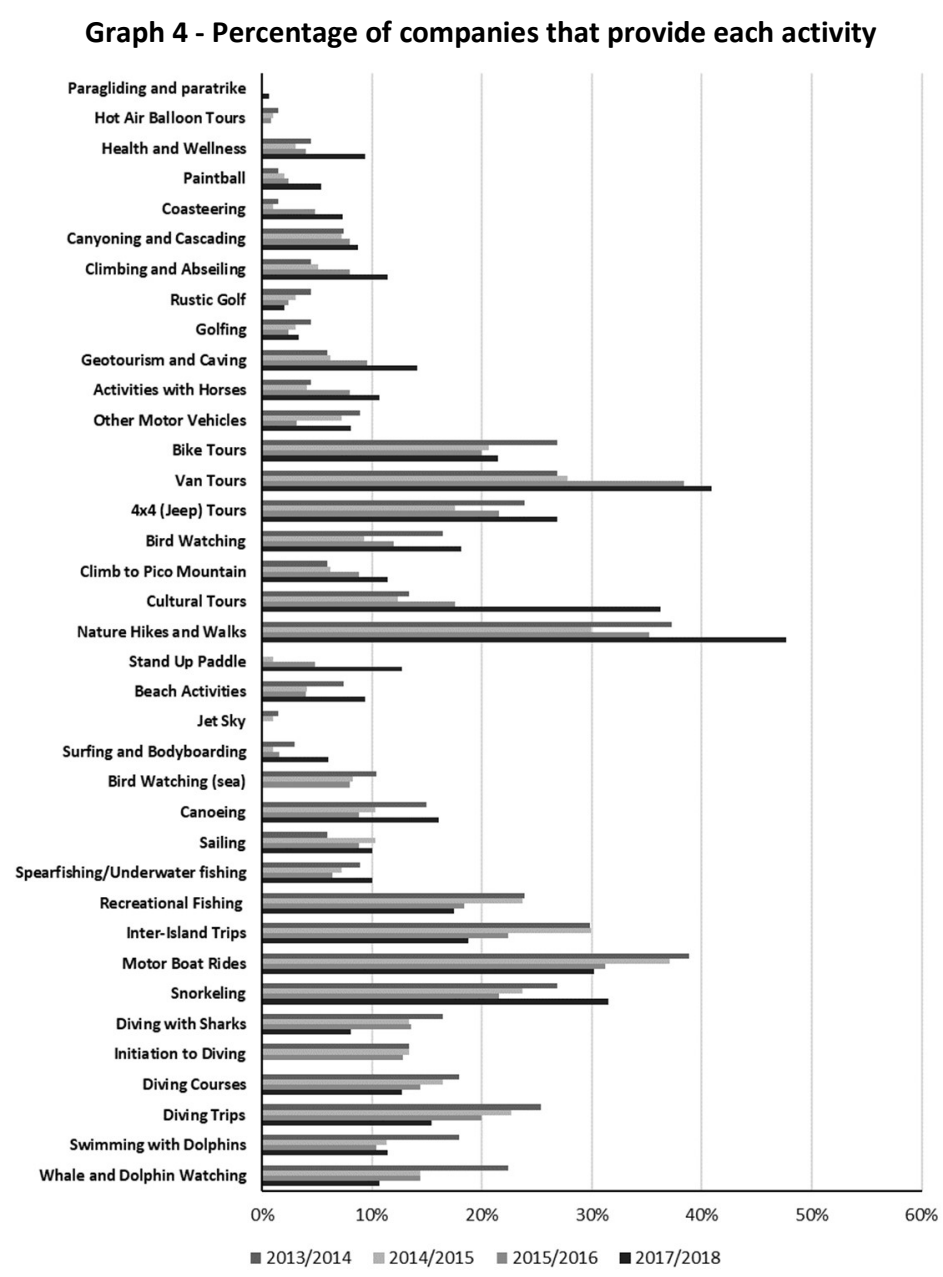

Source: Own elaboration. 
Finally, the assessment of the companies' names/brands shows that explicit references to the Azores are widespread, and around $50 \%$ of the companies use explicit or direct references to the destination (table 6). Not many firms use the word "adventure" in their names, but summing up explicit and indirect references reveals that many companies build their brands around this tourism product/concept.

Table 6 - References to the "Azores" and to "Adventure" in tourism activities companies' names/brands

\begin{tabular}{|l|c|c|c|c|}
\hline & \multicolumn{2}{|c|}{ Azores } & \multicolumn{2}{c|}{ Adventure } \\
\hline & Explicit References & $\begin{array}{c}\text { Explicit and Indirect } \\
\text { References }\end{array}$ & $\begin{array}{c}\text { Explicit and Indirect } \\
\text { References }\end{array}$ \\
\hline $2013 / 2014$ & $32,8 \%$ & $49,3 \%$ & $7,5 \%$ & $49,3 \%$ \\
\hline $2014 / 2015$ & $34,0 \%$ & $45,4 \%$ & $8,2 \%$ & $55,7 \%$ \\
\hline $2015 / 2016$ & $40,8 \%$ & $55,2 \%$ & $8,8 \%$ & $52,8 \%$ \\
\hline $2017 / 2018$ & $38,9 \%$ & $49,0 \%$ & $6,7 \%$ & $52,3 \%$ \\
\hline
\end{tabular}

Source: Own elaboration.

The results show that the number of tourism activities companies registered in the Tourism Activities Guide is increasing in the Azores, and some specific activities have received growing attention from businesses and investors. Some islands are also having a better performance than others, and the activity profile differs across islands. These are some peculiar results that should be discussed considering the particular context of the Azores.

\section{Discussion}

The Azores has been considered one of the most sustainable tourist destinations in the world. The remoteness, natural beauty, and relatively untouched nature allow the development of very diverse, rich, and adventurous tourism products, which embrace the core concept of sustainable tourism (Couto et al., 2017; Moniz, 2009; Santos et al., 2012; Silva \& Almeida, 2013; Vieira et al., 2014). Furthermore, tourism intensity is low, although it has been significantly increasing in the last two years, and many international and independent reports and awards confirm the high sustainability levels of the tourism activities carried on in all the nine islands of the archipelago.

Adventure tourism is an essential tourism product in the Azores. The Tourism Activities Guide, developed by the ATA, indicates that the vast majority of the tourism activities offered by local companies are objectively identifiable as adventurous, accordingly to the ATTA's adventure tourism activities criteria (UNWTO, 2014). This is even more relevant since the international exposure of the region has been positioning the Azores as a nature and adventure destination. The Strategic and Marketing Plan of the Azores Tourism (PEMTA), which was published in 2016, clearly elects Nature Tourism as the "priority product" for the regional tourism development, incorporating many activities identified as adventure tourism, such as hiking, horseback riding, birdwatching, geotourism, mountain biking, canoeing/kayaking, downhill, paragliding, climbing and abseiling, and trekking. Moreover, nautical tourism, cultural touring, and wellness tourism complement this "priority product," and incorporate many activities that are listed on the ATTA's adventure tourism table and correspond to the ATTA's adventure tourism definition.
The number of companies that are listed on the Tourism Activities Guide developed by the ATA has been rapidly increasing, primarily since the new air transport model was implemented (March 2015). This new model has spurred new dynamics in the local economy, revealing the significant influence of the tourism sector on other economic activities, such as commerce or construction activities. For that reason, the interest in tourism has been increasing, and more companies began answering the ATA's survey. Also, a more significant number of companies and small businesses are being set up to capture the opportunities that have emerged from the growth in tourists' arrivals to the region. A more professional approach to communication and promotion from tourism activities companies has been developed. All these phenomena should be further researched upon, as they can represent valuable lessons for destinations that are in the early stages of their life cycle as the Azores.

It is also interesting to notice that, in relative terms, the Cohesion Islands (those that benefit from a positive discrimination in the regional economic policies) have had a more significant increase in the number of companies that is on the guide, although the bigger islands, like São Miguel, still lead in terms of absolute growth. In all islands, tourism has been identified as a viable solution for many economic problems, including unemployment, and has been associated with a new entrepreneurial wave, especially in the smallest islands. Nonetheless, across the nine islands, the evolution of the tourism activities companies listed on the guide has not been uniform, and some islands have had a more regular performance than others. Those that have had more fluctuations are Graciosa, Faial, Flores, and Corvo. Faial, one of the iconic references to sea tourism in the Azores, has had the "least good" performance. On the other hand, Santa Maria has been the top performer every year, even though it is the third smallest island of the archipelago. In turn, São Miguel has been reinforcing its leading position, since more than half of the companies that answered the ATA's questionnaire are operating on this island.

Interestingly, a large portion of the tourism activities companies listed on the ATA's guide tends to have a somewhat limited 
geographic coverage, but this trait became less evident in the 2017/2018 edition. Several companies have been broadening their coverage to more islands. The limited geographic coverage is intriguing, since the islands are small, which reduces market potential, and close to one another, which should ease the movement between them. However, it is widely recognized that the inter-islands transport model - especially air transport - is not very business-friendly and could be causing considerable barriers to the geographical diversification of tourism activities companies. Nevertheless, the new dynamics of the tourism sector is changing this paradigm. In this regard, it should be highlighted that, in the 2017/2018 edition, 11 companies $(7,4 \%$ of the total) are referenced as offering their services in all nine islands. However, eight of those 11 companies offer sea activities based on motorboats or sailboats that allow the necessary mobility between the islands.

The results also show an increasing diversification of the tourism activities in the islands, which means that each island is having more products available, and the supply is becoming more homogeneous across islands (see

Table 7). Only sea and land activities were considered in this approach since air activities have an insufficient supply.

Table 7 - Number of tourism activities available on each island

\begin{tabular}{|c|c|c|c|c|c|c|c|c|c|c|}
\hline & $\begin{array}{l}\text { Santa } \\
\text { Maria }\end{array}$ & $\begin{array}{c}\text { São } \\
\text { Miguel }\end{array}$ & Terceira & Graciosa & $\begin{array}{c}\text { São } \\
\text { Jorge }\end{array}$ & Pico & Faial & Flores & Corvo & Average \\
\hline \multicolumn{11}{|c|}{ Sea Activities } \\
\hline $2013 / 2014$ & 10 & 13 & 15 & 12 & 9 & 10 & 12 & 6 & 2 & 9,9 \\
\hline $2014 / 2015$ & 10 & 16 & 15 & 10 & 4 & 11 & 13 & 6 & 3 & 9,8 \\
\hline $2015 / 2016$ & 11 & 16 & 17 & 9 & 14 & 13 & 13 & 6 & 3 & 11,3 \\
\hline $2017 / 2018$ & 15 & 15 & 14 & 12 & 13 & 14 & 15 & 12 & 12 & 13,6 \\
\hline \multicolumn{11}{|c|}{ Land Activities } \\
\hline $2013 / 2014$ & 5 & 14 & 11 & 6 & 6 & 7 & 7 & 3 & 1 & 6,7 \\
\hline $2014 / 2015$ & 5 & 14 & 13 & 2 & 6 & 8 & 7 & 5 & 2 & 6,9 \\
\hline $2015 / 2016$ & 10 & 15 & 14 & 2 & 11 & 11 & 5 & 4 & 1 & 8,1 \\
\hline $2017 / 2018$ & 14 & 16 & 15 & 10 & 11 & 14 & 15 & 10 & 6 & 12,3 \\
\hline
\end{tabular}

Nevertheless, the number of companies offering each product on each island is very different (see

Table 8), which suggests that each island per se is more prone to a specific category of activities. Sea activities are more widespread in the companies' portfolios than land activities in Santa Maria, Terceira, São Jorge, Faial, Flores, and Corvo. The opposite is true for São Miguel and Pico. There is no clear trend in Graciosa. As a general trend, more and more activities are becoming available on the islands, and some activities are already available in all nine islands. Sea activities are more likely to be available in all islands compared to land activities.

Table 8 - Tourism Activity Categories with more companies, by island

\begin{tabular}{|l|l|c|c|c|c|c|c|c|c|}
\hline & $\begin{array}{c}\text { Santa } \\
\text { Maria }\end{array}$ & $\begin{array}{c}\text { São } \\
\text { Miguel }\end{array}$ & Terceira & Graciosa & $\begin{array}{c}\text { São } \\
\text { Jorge }\end{array}$ & Pico & Faial & Flores & Corvo \\
\hline $\mathbf{2 0 1 3} / \mathbf{2 0 1 4}$ & Sea & $=$ & $=$ & $=$ & $=$ & $=$ & $=$ & $=$ & $=$ \\
\hline $\mathbf{2 0 1 4 / 2 0 1 5}$ & Sea & Land & $=$ & $=$ & Sea & Land & Sea & Sea & Sea \\
\hline $\mathbf{2 0 1 5 / 2 0 1 6}$ & Sea & Land & Sea & Land & Sea & Land & Sea & Sea & Sea \\
\hline $\mathbf{2 0 1 7 / 2 0 1 8}$ & Sea & Land & Sea & Sea & Sea & Land & Sea & Sea & Sea \\
\hline
\end{tabular}

Source: Own elaboration.

Tourism activities companies in the Azores also lean towards specialisation. Their portfolios are small, with an average of four to five activities, although diversification is increasing. Furthermore, companies often stick to a specific category of activities, especially land or sea activities - almost four out of five $(79,2 \%)$ of the companies listed in the $2017 / 2018$ issue were only operating in one category (sea, land, or air). Traditionally, the majority of companies provided sea activities, but recently land activities have become increasingly popular in the companies' portfolios, which may be due to market demand or investment, bureaucracy or technical requirements. This can also be related to some restrictions imposed by the Regional
Government regarding the licenses for some sea activities since pressure on local natural resources and wildlife was increasing. This trend has become more evident since the new air transport model was introduced.

In the 2017/2018 edition, "nature hikes and walks" was the activity that most companies $(47,7 \%)$ offered, and it was available in all the nine islands. Nevertheless, as a result of the general growth of land activities based on motor vehicles (e.g., "van tours," "4x4 (jeep) tours," and "other motor vehicles, like tuk-tuk"), sustainability issues may arise. In the 2013/2014 edition, only 40 companies providing these activities were 
listed, while in 2017/2018 there were 113 companies. This might be relevant regarding sustainability since local diesel, and gasoline consumption is increasing, and traffic congestion may become a problem. Some local attractions are already facing these challenges.

In 2008, the Spatial Plan of Tourism of the Autonomous Region of the Azores (POTRAA) was developed by the Regional Government, which defined it as the fundamental mechanism to achieve the sustainable development of the tourism sector in the region. The document identified the main tourism products for each island and strategically established a specific core tourism product and some other complementary features for each of the nine islands. This was done to serve as a guideline to the islands' tourism development, to mobilise differentiating features and a coherent strategy for the preservation of the environment and cultural identity of each island. These products and resources should influence the regional tourism strategy and local tourism development according to the islands' peculiarities and specific social, economic, environmental, and cultural contexts. More recently, in 2016, the Regional Government published PEMTA, which identified the anchor and relevant products for each island and reviews the POTRAA.

There is a partial overlap between the features identified by these two documents and the most widespread tourism activities in the local companies' portfolios for each island. However, many relevant features are not structured in tourism activities. Some of those features can be (and sometimes are) part of a product mix and not a specific product on their own (e.g., religious traditions, history, and cultural occurrences are often mixed together in cultural tours), while others are publicly available and are not being commonly structured in tourism products through private companies, such as beaches. The present sample does not represent the tourism products' consumption, but instead the private companies' services that are available, therefore leaving behind many products, activities, and features that are provided for free (or not) by public entities.

Although no data is available in the $2017 / 2018$ edition, the $2013 / 2014$ and $2015 / 2016$ editions show that the number of companies providing tourist activities packs steadily increased. This can be a consequence of better preparation of the companies and more professional procedures, which allow for greater value creation for their businesses as well as a better experience for tourists. Further research is needed to understand how product structuring, cross-selling, and bundling are being developed by local companies.

Regarding naming/branding, a large share of companies uses explicit references to the Azores, and around $50 \%$ of the sampled firms have explicit or indirect references to the region. This could outline a strategy with many different purposes, including the quick identification with the destination, the brand build-up around the Azores distinguishing features (like sustainability or nature) or its strategic positioning (as nature and adventure destination) and, on a digital perspective, a search engine optimisation approach. Moreover, adventure and the adventurous experience as a whole are essential features in companies' brands, although not many use the word adventure explicitly (around 6\% to $9 \%$ ). In this regard, it is relevant to remind that UNWTO's (2014) Global Report on Adventure Tourism clearly states that the number of companies with adventure as primary brand identity is on the rise, and many big tour operators are creating their specific brands for adventure tourism to meet the growing market demand.

\section{Conclusions}

Although this study helps address some open questions from the reference literature, it suffers some limitations. The present analysis is exclusively based on information obtained from the official Tourism Activities Guide, which does not incorporate all the companies that operate in this market in the Azores. The general profile of the companies and their product's portfolios may only partially represent the market as a whole, although the sample is substantial and quite detailed.

Also, the different dynamics in each island should be further researched upon, as there could be fundamental traits and features that stimulate or break the tourism activities companies' competitiveness and market dynamics, including economic aspects, sociocultural features, natural constraints or even political decisions. Future research should also evaluate those companies' involvement in sustainability practices and their contribution to a broader sustainable tourism development strategy, identifying eventual differences between islands and tourism activities. Research based on a different type of information should also be developed to understand whether adventure tourism products in the Azores follow the pattern identified by Buckley (2007), including group size (around $66 \%$ of tours take 6 to 20 clients at a time) and guide-client ratio (which range from 5:1 to 7:1).

The results from this study can contribute to a better understanding of tourism activities and companies on small, nature-based, adventurous and sustainable island destinations. It could be interesting to compare these results with research regarding the companies' profile and their portfolios on other destinations, like Iceland or the Faroe Islands. Additionally, the results can have significant implications on the local tourism sector and provide more detailed knowledge about the evolution of the local tourism companies, the activities they are offering, their brands and their geographic coverage. This is important information for strategic planning, marketing and destination planning. Moreover, it can be relevant for government bodies when issuing permits and licenses, but also when considering sustainability issues, especially considering smaller islands, their carrying capacity and the competitive level of SMEs in these places. 


\section{Acknowledgements}

The authors would like to thank the Associação de Turismo dos Açores - Conventions and Visitors Bureau (ATA) for the support and the information made available and to Fundo de Maneio for the opportunity to work on this paper, which was developed under the NaTOUReza Project (ACORES-01-0247-FEDER-000004). This paper was financed by Portuguese national funds through FCT - Fundação para a Ciência e a Tecnologia, I.P., project number UID/ECO/00685/2016.

\section{References}

Arnegger, J., Woltering, M., \& Job, H. (2010). Toward a product-based typology for nature-based tourism: a conceptual framework. Journal of Sustainable Tourism, 18(7), 915-928. doi: 10.1080/09669582.2010.485680

Ayala, H. (1996). Resort Ecotourism: A Paradigm of the 21st Century. Cornell Hotel and Restaurant Administration Quarterly, 37(5), 46-53. doi: 10.1016/0010-8804(96)88974-9

Baldacchino, G. (2006). Warm versus cold water island tourism: A review of policy implications. Island Studies Journal, 1(2), 183-200.

Buckley, R. (2006). Adventure tourism research: a guide to the literature. Tourism Recreation Research, 31(2), 75-83. doi: 10.1080/02508281.2006.11081265

Buckley, R. (2007). Adventure tourism products: price, duration, size, skill, remoteness. Tourism Management, 28(6), 1428-1433. doi: 10.1016/j.tourman.2006.12.003

Buhalis, D. (2000). Marketing the competitive destination of the future. Tourism Management, 21(1), 97-116. doi: 10.1016/S02615177(99)00095-3.

Butler, R. (1980). The concept of a tourist area cycle of evolution: Implications for management of resources. Canadian Geographer, 24(1), 5-12. doi: 10.1111/j.1541-0064.1980.tb00970.x

Cole, Z. (2016). Identifying adventure tourism product signatures: a case analysis of guided mountain bike tours. E-Review of Tourism Research (eRTR), 13(3/4), 490-500.

Couto, G., Pimentel, P., \& Ponte, J. (2017). Tourism Development Potential in an Insular Territory: The Case of Ribeira Grande in the Azores. Journal of Tourism Research \& Hospitality, 6(2). doi: 10.4172/2324-8807.1000166

Giddy, J. (2017). A profile of commercial adventure tourism participants in South Africa. Anatolia: An International Journal of Tourism and Hospitality Research, 1-12.

Goodwin, H. (1996). In pursuit of ecotourism. Biodiversity and Conservation, 5(3), 277-291.

Kozak, M. (1999, September). Destination Competitiveness Measurement: Analysis of Effective Factors and Indicators. Paper presented at the $39^{\text {th }}$ European Regional Science Association Conference. Vienna: European Regional Science Association.

McMinn, S. (1997). The challenge if sustainable tourism. The Environmentalist, 17, 135-141.

Moniz, A. (2009). A Sustentabilidade do Turismo em Ilhas de Pequena Dimensão: O Caso dos Açores. Ponta Delgada: Centro de Estudos de Economia Aplicada do Atlântico - CEEApIA.

Santos, C., Couto, G., Pimentel, P., \& Vieira, J. (2012). Quality of the Azores destination in the perspective of tourists. Tourism and Hospitality Research, 12(1), 32-42. doi: 10.1177/1467358411429639

Scarpaci. C., Dayanthi, N., \& Corkeron, P. (2003). Compliance with regulations by "swim-with-dolphins" operations in Port Philip Bay, Victoria, Australia. Environmental Management, 31(2), 342-347. doi: 10.1007/s00267-002-2799-z

Silva, F. \& Almeida, M. (2013). Sustentabilidade do turismo na natureza nos Açores - O caso do canyoning. Em Almeida, M. (Ed.), Turismo e desporto na natureza, (pp. 5-19), Estoril: Associação de Desportos de Aventura Desnível.
Smith, S. (1994). The tourism product. Annals of Tourism Research, 21(3), 582-595. doi: 10.1016/0160-7383(94)90121-X

Steynberg, L., \& Grundling, J. (2005). Sustainability of adventure tourism: The economic highway. Sustainable Development and Planning II, WIT Transactions on Ecology and the Environment, 84(2), 1419-1428. doi: 10.2495/SPD051392

Tshipala, N., Coetzee, W., \& Potieter, M. (2014). Stakeholder's views of sustainable adventure tourism indicators: a cluster analysis methodology. African Journal for Physical, Health Education, Recreation and Dance (AJPHERD), 20(1), 40-51.

UNWTO (2014). Global Report on Adventure Tourism (AM Reports: Volume Nine). Retrieved from UNWTO: http://cf.cdn.unwto.org/sites/all/files/pdf/final_1global_report_on_ad venture_tourism.pdf

Vieira, J., Couto, G., Pimentel, P., Menezes, A., Moniz, A., \& Sousa, F. (2014). The Satisfaction of the Nordic Tourist with the Azores as a Destination. Scandinavian Journal of Hospitality and Tourism, 13(1), 5973. doi: 10.1080/15022250.2014.959806

\section{Received: 15 May 2018}

Revisions required: 22 July 2018

Accepted: 14 September 2018 